\title{
Social Values and Prostitution in Awka South Local Government Area, Anambra State, Nigeria
}

\author{
Nneka P. Oli \\ Department of Sociology/Anthropology \\ Nnamdi Azikiwe University, Awka \\ Anambra State, Nigeria \\ np.oli@unizik.edu.ng/nnekaoli@yahoo.com
}

DOI: $10.36108 / \mathrm{NJSA} / 3102 / 11(0160)$

\begin{abstract}
In every society, there are certain cultural values and value systems that guide every aspect of human behaviour. In Nigeria, our value system is in the process of decaying. This may be attributed to alien values of colonialism, imperialism and neo-colonialism. Prostitution which is regarded as a crime against morality, societal standard of right conduct and decency may be traced to western influence and decline in social values. This paper investigated the impact of declining social values on prostitution among females in Awka South LGA in Anambra State. The study adopted strain theory as its theoretical framework. The target population for the study comprises people who are 18 years and above. Multi-stage sampling technique was adopted in selecting 200 respondents for the study. Quantitative and qualitative methods of data collection were used in this study. In view of this, questionnaire and in-depth interviews were the instruments of data collection used in the study. The findings indicate that decline in social values, poverty, and unemployment are major factors influencing prostitution. Therefore, the study recommends that all agents of socialization should ensure that our social values are maintained by inculcating these values in our youth. Also, efforts should be made to alleviate poverty and unemployment in our society which also tend to drive prostitution.
\end{abstract}

Keywords: social values, prostitution, child abuse, human trafficking, Awka

\section{Introduction}

The phenomenal increase in social problems across the globe and especially in the developing countries is worrisome. The situation becomes serious when the problem is multi-dimensional in nature. Prostitution has been identified by scholars (Dworkin, 1992; Raymond, 1999; Cockayne, 2001) as a global social and urban problem which has pervaded every dimension of human survival. The phenomenon is not peculiar to developing countries; the enormity of prostitution throughout the world is overwhelming. Across the globe, it has become a prominent social problem. The presence of prostitutes in the major urban centres of the world, especially in the industrialized countries, has transcended the level it was viewed as strictly uncommon occurrence to a worrisome global problem (Ogunkan, Omoruan \& Fawole, 2012).

In Africa, where the problem of prostitution is relatively new, unlike the situation in Europe and other industrialized countries, the presence of large number of prostitutes has now become a major issue. The unprecedented growth of the sex industry in Africa may not be unconnected with the rapid and 
wide ranging socio-economic changes and globalization which have affected the value structure of African society. Nigeria is not spared of this scourge and prostitution has become so prominent that Nigerians refer to it as "the Italian Connection", "sex working", "Ashawo business" (Obinna, 2005). The outburst of prostitution in Nigeria, in a way, is comparable to western societies where the sex trade has posed a moral challenge. The alarming dimension of this menace can be seen not only through the proliferation of brothels and hotels for sex workers in most urban centres but also in the increasing of prostitution rings in the country (Adesina, 2006).

This phenomenon has not only attracted public concern but has also become a matter of academic concern (Ausbeth-Ajagun, 2005; Obinna, 2005; Adesina, 2006; Uzokwu, 2008; Adeyinka, 2008; Accusy, 2009). However, with few exceptions on socio-cultural and socio-economic issues, most of these scholars focused on health dimensions of the problem while neglecting the environmental implications of prostitution.

It has been observed that changing social values have greatly affected the behaviour of individuals in the society. In Nigeria, prostitution may be attributed to the decay in the value systems. In traditional African society, certain social values were indispensable; every society has its set of values which guides every aspect of human behaviour. These cultural values or value systems regulate human relationship. Value system simply refers to the cultural outlook of the people, and the understanding of the value system of the people is the understanding of the belief system and cultural system of the people (Akinpelu, 1983). This study is concerned with social values which appear to be the bedrock of African cultural values and they comprise other types of values mentioned in this paper. According to Iroegbu (1994), there are enduring social values which in spite of the invasion and the encroachment of Western value system remain the same.

Prostitution is the sale of sexual services for money. A person selling sexual services is a prostitute, a type of sex worker. Many religions regard prostitution as improper or sinful and prostitutes are also regarded as shameful and individuals of low standing in many societies. Male customers of prostitutes are known as clients, johns or punters. Female prostitutes may also be called whore, sex worker, hooker, call girl, courtesan or escort (Brewer, 2000). Organizers of prostitution are known as pimps (usually males and most often with regard to street prostitution) and madams (usually females with regard to brothel prostitution).

The international trafficking of persons, especially of women and children, for prostitution and other purposes is a global scourge and also a social problem. Trafficking and prostitution entail the use of women and young girls for commercial sexual exploitation. The commercialization of women's bodies is tolerated and indeed encouraged to satisfy male sexual needs and desires and defended as a resolution to problems of male sexuality and sexual identity and the relational problems of men. Prostitution is defined as the oldest profession and it continues to be accepted as an integral part of the social exchange 
between men and women while the inherent violence contained such an exchange is often denied and left to perpetuate itself (Aghatise, 2002).

In most African countries such as Togo, Gabon, Republic of Benin, Cameroun and Nigeria, prostitution is illegal. This is because prostitution is regarded as an offence that violates the society's standard of right conduct and decency. Igbo (2007) classified prostitution as one of the offences against public morality. It is a common practice influenced by societal denial and weak political commitment, social inequality, gender divisions, human right abuse, lack of dialogue about sex and sexuality, social breakdown caused by the civil war or economic collapse, and most importantly by the widespread poverty in several Sub-Saharan African countries, including Nigeria (Uzokwe, 2008).

Prostitutes are often under the fear of violence from their clients; physical abuse was considered a part of the job of prostitution with the payment sometimes determined by each individual, beating or whipping are forms of physical abuse that prostitutes undergo (Farley, 2006). Other dangers associated with prostitution are spread of Sexually Transmitted Diseases (STDs) such as gonorrhoea, syphilis, Human Immune Deficiency Virus (HIV), Acquired Immune Deficiency Syndrome (AIDS), unwanted pregnancy, ritual and murder. Many studies on prostitution have not actually tried to find out the relationship between declining social values and prostitution in the society.

The present study explores this angle because there is a general belief that poverty and unemployment are the major socio-economic variables that may influence prostitution. Therefore, the study sought information from residents of Awka South Local Government Area, Anambra State, Nigeria, on the impact of changing social values on prostitution. In order to obtain this information, the following questions were asked: What are the factors influencing prostitution? What is the relationship between declining social values and prostitution? The objectives of the study are: to examine the factors influencing prostitution, and to ascertain the relationship between declining social values and prostitution.

\section{Social and Economic Factors Influencing Prostitution}

Scholars have come out with considerable number of closely related factors influencing prostitution. The internet survey conducted by Ausbeth-Ajagun (2005) showed greed and avarice, broken home, poor parental upbringing, deceptive media appeal, godlessness, distorted value system and ignorance as factors influencing prostitution. These factors were corroborated by Obinna (2005) who identified poverty, harsh economic condition and abandonment by family members as factors influencing prostitution in Nigerian urban centres. Adesina (2006) also identified poverty, inadequate job opportunities, greed, laziness, harsh economic condition and distorted value system.

Prostitution in Nigeria may be attributed to factors like poverty, breakdown of social and cultural values, the disintegration of family structures and lack of valid efficient social reference models that replace traditional models. In this 
context, sending female children abroad, in most cases has become a status symbol for families (Aghatise, 2001). Many families believe that it is easy to obtain wealth abroad and that earning money in whatever way will be quick. There are women who engage in prostitution as a result of poverty but they withstand the hardships of the profession until they can find something else to do. However, there are women born poor into families with a long history of poverty and a lack of education. In some situations, a woman may be abducted against her will for no reasons of defect in her character and be forced into prostitution. Nevertheless, a woman might voluntarily enter the profession because of defects in her moral character that allow her to fall into association with violent and exploitative social predators who, like her, do not wish to follow the rules of any legal or moral system. She associates with people in an intimate way, well beyond the protection of police or the assistance of social agencies that can effectively assist her in fighting off abuse. There is a relationship between working within the social value system and abuse. It can be said that there is potentially a cost for deviating too far from social values (Nozick, 1981).

According to Conne (2010), many females in the higher institutions of learning engage in prostitution to finance their education. Some students who are not satisfied with the little finance and other provisions that their parents give them engage in prostitution to live big on campus, riding posh-cars, living in tastefully furnished rented apartments, owning fat bank accounts and wearing designer dresses, shoes and bags which are direct consequence of the materialistic economy. He went further to state that some of these girls engage in prostitution after graduating from the university and failing to secure gainful employment, having roamed the streets for jobs without success and having no capital to start any business. Subsequently, such girls may be tempted to engage in sexual activities in exchange for money. Some desperate families force their own children into prostitution. Other young people are unwittingly lured into prostitution by responding innocently to advertisements for entertainers or dancers (Giddens, 2008). In his own contribution, Gibbe (2001) maintained that the reasons people indulge in prostitution include discrimination against women in the society and lack of finances. Some feminists argue that in most cases, prostitution is not a conscious and calculated choice; most women who become prostitutes do so because they were forced or coerced by human traffickers, or when it is an independent decision, it is generally the result of extreme poverty and lack of employment opportunity.

\section{An Overview of Reasons for Indulging in Prostitution}

In Aghatise (2001) study in the South-Central Zone of Nigeria, the respondents appeared to accept the idea of prostitution as one solution to extreme poverty or financial disadvantage. Also, the findings of the study clearly showed that some families encourage their daughters to accept offers from traffickers who take the young girls and women abroad. Some of these young girls have been thrown out of their homes when they refused to follow their families' wishes. 
Ogunkan, Omoruan and Fawole (2012) conducted a study on prostitutes in Ogbomoso, Oyo State, Nigeria, on environmental and socio-economic conditions of prostitution. The findings of their study showed that poverty, harsh economic condition, family disruption, coercion, child abuse or neglect were identified as factors responsible for prostitution. The study also indicated that effects of prostitution include increase in violent behaviour, moral decadence, criminal tendency of youths, teenage pregnancy, abortion, nude dressing, underage sexual experience, hemp smoking and alcohol taking.

In a study by Mclyntyre (2000) on the reasons for indulging in prostitution, it was found that the decision to prostitute must be understood within social structural issues such as patriarchy, capitalism, subordinate position of women and lack of economic opportunity. Another study conducted by Manson (2001) in Sweden indicated that difficult childhood including sexual abuse, emotionally negative parents and other types of social problems are reasons for indulging in prostitution. According to him, the process of becoming involved in prostitution was influenced by the previous destructive events accompanied by feeling of low self esteem.

From Sharpe's (1999) study in England on the reason why some women become prostitutes, it was observed that associates are an influence although not a single cause. In some cases, family members and friends acted as motivators and mentors to the novice prostitute. There is also the significance of adolescence peer pressure. Factors that make prostitution an apparently attractive choice include broken homes and sexual abuse combined with a personality type that craves for excitement and easy money. The single most common character of all the women in the sample was lack of education and employment qualification. Most women believe that prostitution is a rational economic choice - easy money for little effort.

\section{Theoretical Framework}

This study is anchored on the strain theory. Merton (1957) developed this theory by adapting Durkheim's notion of anomie. According to Merton, deviance may be attributed to the strain people experience as a result of the disjuncture between cultural goals and the socially approved means for achieving these goals. In the society, there are socially acceptable ways of becoming successful - follow the rules, work hard, get a good education and get a good job. However, in the real world, the poor and lower class are at a disadvantage because they have little formal education and few economic resources with which to create opportunities for themselves. Such groups of people are likely to experience strain which may lead to deviance.

Merton identified five modes of adaptation to this goal/means dilemma. They include conformity, innovation, ritualism, retreatism and rebellion. Only the first adaptation in Merton's typology, conformity, involves following the norms, the four remaining are deviant adaptations. For the purposes of this study, only the second mode of adaptation, innovation, will be discussed. 
Innovation is a situation where the goal is accepted but the means are rejected and replaced with unconventional, inappropriate and illegal means. For instance, some people may sell their bodies to obtain material symbols of success. These prostitutes reject the social values of hard work and resort to deviant behaviour in order to acquire wealth. This mode of adaptation best explains the social phenomenon of prostitution, and the strain theory is the most suitable, relevant and appropriate framework for examining this phenomenon in Awka.

\section{Method}

\section{Sample and Sampling Procedure}

The study was carried out in Awka South Local Government Area (LGA) in Anambra State, Nigeria, in 2012. It adopted a cross sectional survey design. According to 2006 National Population figure, Awka South L.G.A. has a population of 189,654 made up of 97,000 females and 91,806 males. The target population for this study were adults aged 18 years and above. The multi-stage sampling method that involves successive random sampling was employed in selecting communities, villages, streets, households and respondents in the study. The multi-stage design was very relevant because the study population was very large and made up of several clusters like towns, villages and households.

A sample size of 200 was used for the study and the major instrument for collecting data was the questionnaire. A uniform set of questionnaires were administered to all the respondents. Complementary instrument like In-depth Interviews (IDIs) were used in the study to support and elucidate the quantitative data. Four IDI's were conducted with two males and two females purposively selected based on their knowledge of the subject matter. Care was taken to maintain gender balance in the selection of interviewees who participated in the survey. Out of the 200 questionnaires distributed, 194 were correctly filled and returned, giving a response rate of 97 percent.

\section{Data Analysis}

The researcher got approval from the respondents before administering the questionnaires. The interviewees gave their consent before the in-depth interviews were conducted. Data were analyzed using Statistical Package for Social Sciences (SPSS). Descriptive statistics such as frequencies and percentages were used to analyze the quantitative data. For the qualitative data, in-depth interviews were subjected to content analysis. However, illustrative quotes were identified and organized under distinct themes.

\section{Results}

\section{Characteristics of Respondents}

Table 1 presents the socio-demographic characteristics of the respondents. The table clearly indicates that majority of the respondents were ages 18-28 and 2939 with $35.1 \%$ and $34.5 \%$ respectively. About $53 \%$ of the respondents were males while the remaining $47 \%$ were females. In terms of marital status, the 
majority of the respondents $(58.8 \%)$ were single while $1.5 \%$ of them were widowed. The educational qualification of the respondents shows that the majority of them had secondary school education (52.1\%), and 36.6\% have university and polytechnic education. About $37 \%$ were civil servants, and $31.4 \%$ were apprentices. The religious affiliation of the respondents shows that $87.6 \%$ were Christians while $12.4 \%$ were Moslems.

Table 1: Distribution of respondents by socio-demographic characteristics

\begin{tabular}{|l|c|c|}
\hline \multicolumn{1}{|c|}{ Socio-Demographic } & Frequency & Percentage \\
\hline Age & & \\
\hline $18-28$ & 68 & 35.1 \\
\hline $29-39$ & 67 & 34.5 \\
\hline $40-50$ & 43 & 22.2 \\
\hline Above 50 & 16 & 8.2 \\
\hline Total & $\mathbf{1 9 4}$ & $\mathbf{1 0 0 . 0 0}$ \\
\hline Sex & & \\
\hline Male & 102 & 52.6 \\
\hline Female & 92 & 47.4 \\
\hline Total & $\mathbf{1 9 4}$ & $\mathbf{1 0 0 . 0}$ \\
\hline Marital Status & & \\
\hline Single & 114 & 58.8 \\
\hline Married & 77 & 39.7 \\
\hline Widowed & 3 & 1.5 \\
\hline Total & $\mathbf{1 9 4}$ & $\mathbf{1 0 0 . 0 0}$ \\
\hline Educational qualification & & \\
\hline Primary & 5 & 2.6 \\
\hline Secondary & 101 & 52.1 \\
\hline NCE/OND & 17 & 8.7 \\
\hline B.Sc/HND/M.Sc/Ph.D & 71 & 36.6 \\
\hline Total & $\mathbf{1 9 4}$ & $\mathbf{1 0 0 . 0}$ \\
\hline Occupation & & \\
\hline Unemployed & 15 & 7.7 \\
\hline Civil Servant & 72 & 37.1 \\
\hline Apprentice & 61 & 31.4 \\
\hline Business/Trading & 44 & 22.7 \\
\hline Student/other & 174 & $\mathbf{1 0 0 . 0}$ \\
\hline Total & 24 & $\mathbf{1 0 0 . 0}$ \\
\hline Religious affiliation & $\mathbf{1 9 4}$ & \\
\hline Christian & & \\
\hline Moslem & & \\
\hline Total & & \\
\hline & & \\
\hline & & \\
\hline
\end{tabular}


The table implies that most of the respondents were young. It is not surprising that the majority of the respondents were single considering their age at the time the study was conducted. However, at this age most of the respondents had only secondary education. It is noteworthy that most of the respondents were Christians considering the fact that the study was conducted in the Eastern part of Nigeria where Christianity is the dominant religion. The study area, Awka is the capital of Anambra State with many government parastatals and this may be the reason why a large number of the respondents were civil servants.

\section{Respondents' views on factors that influence prostitution in Awka South $\boldsymbol{L G A}$}

Respondents were asked to identify the factors that may influence prostitution. Their responses are shown in Table 2 below.

Table 2: Distribution of respondents according to their views on factors influencing prostitution

\begin{tabular}{|l|c|c|}
\hline Factors influencing prostitution & Frequency & Percentage \\
\hline Poverty & 70 & 36.0 \\
\hline Low academic qualification & 8 & 4.2 \\
\hline Unemployment & 86 & 44.3 \\
\hline Declining social values & 22 & 11.3 \\
\hline Peer pressure & 8 & 4.2 \\
\hline Total & $\mathbf{1 9 4}$ & $\mathbf{1 0 0 . 0}$ \\
\hline
\end{tabular}

Table 2 shows that most of the respondents believed that unemployment was the main factor influencing prostitution, and $36.0 \%$ believed that poverty influences prostitution. Other factors include: decline in social values $(11.3 \%)$, low academic qualification and peer pressure ( $4.2 \%$ each).

Looking at the table, one could infer that poverty and unemployment were the major socio-economic variables that may influence prostitution. The views of the respondents were not different from the factors identified in the literature. It should be noted that many social problems and criminal activities in Nigeria are also attributed to high levels of poverty and unemployment in the country.

When one of the IDI respondents was asked what she thought was the major factor that contributes to prostitution, she replied:

Poverty is the major factor that encourages prostitution. Some of these women engage in prostitution as last resort. They believe that they should use what they have to get what they want (Female, trader, 40 years). 
Respondents' views on the relationship between declining social values and prostitution

Respondents were asked whether there is a relationship between declining social values and prostitution. Their answers are displayed in Table 3.

Table 3: Distribution of respondents according to their views on the relationship between declining social values and prostitution

\begin{tabular}{|l|c|c|}
\hline \multicolumn{1}{|c|}{ Social Values and Prostitution } & Frequency & Percentage \\
\hline $\begin{array}{l}\text { Decay in culture encourages } \\
\text { prostitution }\end{array}$ & 14 & 7.2 \\
\hline $\begin{array}{l}\text { Lack of hard work encourages } \\
\text { prostitution }\end{array}$ & 2 & 1.0 \\
\hline $\begin{array}{l}\text { Western culture impacts negatively on } \\
\text { social values }\end{array}$ & 68 & 35.1 \\
\hline Urbanization encourages prostitution & 43 & 22.2 \\
\hline $\begin{array}{l}\text { Prostitution encourages moral } \\
\text { decadence }\end{array}$ & 67 & 34.5 \\
\hline Total & $\mathbf{1 9 4}$ & $\mathbf{1 0 0 . 0}$ \\
\hline
\end{tabular}

Table 3 shows that $35.1 \%$ believed that western culture impacts negatively on our social values, $22.2 \%$ believed that urbanization encourages prostitution, while $34.5 \%$ believed that prostitution encourages moral decadence in the society. The table implies that western culture does more harm than good to the indigenous social values. For instance, socio-economic changes and globalization have negative impact on the behaviour of individuals in the society.

A male IDI interviewee noted that:

Prostitution is a very common phenomenon in Nigerian society and even in Awka here. In traditional society, women were more decent and morally upright but today due to civilization, modernization, industrialization and urbanization, our social values are declining and impacting negatively on the behaviour of females. This may be the reason for high level of prostitution in our society (Male, lawyer, 50 years).

A female IDI respondent with a rather different opinion on the factors that influence prostitution noted that:

Inadequate socialization, weak ties between parents and their children, peer group influence, broken homes are some of the factors that influence prostitution which is a deviant behaviour in the society. (Female, student, 21 years) 


\section{Discussion}

This study examined the views about factors that influence prostitution and the impact of changing social values on prostitution among residents of Awka South LGA in Anambra State, Nigeria. The findings from the study indicated that respondents identified different factors that may influence prostitution. It is interesting to note that majority of the respondents believed that unemployment was a major factor. This is not strange because the situation in Nigeria propels some individuals who are unemployed to engage in criminal and deviant behaviours in order to survive. Unemployment gives rise to poverty which is the order of the day in Nigeria. The findings are in agreement with those of Ogunkan, Omoruan \& Fawole (2012) who, in their study in Ogbomoso, Oyo State, indicated that poverty, harsh economic condition, family disruption, coercion, child abuse or neglect are factors which may influence prostitution.

Nonetheless, it is rather interesting to know that many residents of Awka South LGA believed that Western culture has a negative impact on the social values. This is based on the fact that most people borrow some cultural values from the West in erroneous belief that their culture is superior to the Igbo or Nigerian culture. It has been observed that Nigerians prefer western culture and they do not cherish their own culture. In a study conducted by Aghatise (2001) in the South-Central zone of Nigeria, it was observed that people appeared to accept the idea of prostitution as one solution to extreme poverty or financial disadvantage. The breakdown of social and cultural values and the disintegration of family structures are among the factors that may influence prostitution in Nigeria. Sharpe (1999), in his study in England, identified other factors like adolescence peer pressure, broken homes, sexual abuse, lack of education and employment opportunity.

This study corroborates the prescriptions of the strain theory. Unemployment and poverty are the strain experienced by people, which in turn, provide the conducive environment for females to engage in prostitution as a way to make both ends meet. Merton's strain theory states that prostitution is an unconventional, inappropriate and illegal means of achieving success (obtaining wealth) in the society. This was emphasized in his mode of adaptation known as innovation. Therefore, the theoretical framework strongly supports the findings of the study.

\section{Conclusion}

Prostitution is a common phenomenon in Nigeria. Several factors such as poverty, unemployment, peer pressure and declining social values have been identified as influencing factors. Globalization and socio-economic changes have tremendous negative impact on the personality development and character formation of youth. It is important that these issues are addressed in order to control the high rate of prostitution in Nigerian society.

\section{Recommendations}

This study suggests that the family, community, government and policy makers have some roles to play in alleviating prostitution in our society. Government 
should endeavour to put machineries in place to address the economic situation and the incidence of poverty in the country. Also, job opportunities should be created by the government to meet the problem of unemployment in the country. Efforts should be made to uphold the cherished Igbo social values and inculcate these values in the younger generation, who will in turn do so to their own children. This will go a long way to make the youth appreciate and cherish the Igbo or Nigerian cultural values.

\section{References}

Accusy, A. 2009. Prostitution trade swells due to hard times. Nigerian Tribune Newspaper. 8.

Adesina, O.A. 2006. Between culture and poverty: The Queen mother phenomenon and Edo International sex trade. A Journal of Culture and African Studies. Issue 8.

Adeyinka, R.Q. 2008. Socio-environmental impact of brothels (Red Light Zone) on residential neighbourhood of Ogbomoso B. Tech Dissertation. Department of Urban and Regional Planning, Ladoke Akintola University of Technology, Ogbomoso.

Aghatise, E. 2001. Research and case studies on the international trafficking of Nigerian women and girls for prostitution on Italy. Unpublished.

Aghatise, E. 2002. Provision of assistance to victims, best practices study and inter-agency co-operation in combating traffick in women in Italy. Unpublished report. Turin, Italy: Associazione.

Akinpelu, J.A. 1983. Values in Nigerian Society, in New Perspectives in Moral Education. Otonti, A.; Ndubuka and E.O. Iheoma (eds.). Ibadan: Evans Brothers Nigerian Publishers Ltd.

Ausbeth-Ajagun, A. 2005. Prostitution. Youth and Gender Network. http/www. youthgendernetwork.com.

Brewer, D. 2000. Prostitution and the sex discrepancy in reported number of sexual partners. Proceeding of the National Academy of Science. USA. 97(22):1238512388.

Cockayne, A. 2001. Prostitution and sexual exploitation in the European Union. The politics of policing transnational crime in Europe. Department of Politics, University of Exeter. Retrieved from http/www.ex.ac.uk/politics/poldata.

Conne, K. 2010. Prostitution and its consequences on the female child. National Journal of Humanities. (3)7.

Dworkin, A. 1992. Prostitution and male supremacy. A speech delivered at a symposium entitled Prostitution: from Academia to Activism. 
Michigan Journal of Gender and Law. University of Michigan Law School.

Farley, M. 2006. Prostitution. Factsheet on human rights violations. Prostitution Research and Education.

Gibbe, E. 2001. Confronting the liberal lies about prostitution in D. Leidholdt and J. Raymond.

Giddens, A. 2008. Sociology. USA: Policy Press.

Igbo, E.U.M. 2007. Introduction to Criminology. Nsukka: Afro-Orbin Publishers.

Iroegbu, P. 1994. Enwisdomization and African Philosophy. Owerri: International Universities Press.

Mansson, S.I. \& Hedin, U. 2001. Women leaving prostitution. International Journal of Social Welfare. 8:67-77.

Mclyntyre, S. 2000. Strolling away from morality. Canada: Department of Justice, Research and Statistics.

Merton, R. 1957. Social Theory and Social Structure. New York: Free Press.

Nozick, R. 1981. Philosophical explanations. Harvard: Belknap.

Obinna, C. 2005. Story that touches the heart. Why prostitution rate is rising. Vanguard Newspaper. December 31. 10.

Ogunkan, D.V., Omoruan, A. \& Fawole, O. 2012. Environmental and socio-economic dimensions of prostitution in Ogbomoso, Oyo State. Ile-Ife. Research Publications in Geography.

Raymond, J.G. 1999. Health effect of prostitution. Coalition against trafficking in women.

Sharpe, K. 1999. Prostitutes, punters and the police. England: Ashgate Publishing.

Uzokwe, M. 2008. Causes of Prostitution in Contemporary Nigerian Society. Enugu: John Jacobs.

Uzokwu, A.O. 2008. Prostitution in Nigerian University Campuses (part

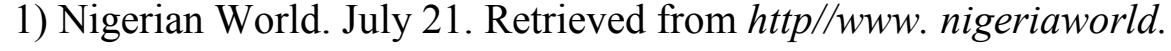
com. 